\title{
PEMBELAJARAN E-LEARNING BERBASIS EDMODO DENGAN PENDEKATAN CONTEXTUAL TEACHING AND LEARNING TERHADAP KEMAMPUAN BERPIKIR KRITIS PESERTA DIDIK
}

\author{
Diana Kuji Kalinggoru, Desak Nyoman Budiningsih, Ida Bagus Ari Arjaya \\ Program Studi Pendidikan Biologi, Universitas Mahasaraswati Denpasar \\ Email: dyanakalinggoru@gmail.com
}

\begin{abstract}
ABSTRAK
Edmodo merupakan aplikasi edukasi dengan platform media sosial menyerupai facebook yang dapat digunakan dalam pembelajaran. Pada umumnya para guru masih jarang memanfaatkan pembelajaran berbasis informasi, komunikasi dan teknologi, dan hanya fokus pada pembelajaran dengan menggunakan Liquid Crystal Display (LCD) saja tanpa memanfaatkan aplikasi teknologi secara maksimal untuk keperluan pendidikan. Tujuan dari penelitian ini adalah untuk untuk menganalisis perbedaan kemampuan berpikir kritis antara peserta didik yang diterapkan pembelajaran E-Learning berbasis Edmodo tanpa pendekatan Contextual Teaching and Learning $(C T L)$ dengan peserta didik yang diterapkan pembelajaran E-Learning berbasis Edmodo dengan pendekatan Contextual Teaching and Learning (CTL). Jenis penelitian ini adalah Quasi Experimental Design dengan rancangan penelitian Nonequivalent Control Group Design yang dilaksanakan di SMA (SLUA) Saraswati 1 Denpasar mulai dari bulan Februari sampai April. Sampel pada penelitian ini adalah peserta didik kelas X MIA 5 sebagai kelas kontrol dan kelas X MIA 1 sebagai kelas eksperimen. Kemampuan berpikir kritis diukur menggunakan tes essay dengan menggunakan rubrik penilaian kemampuan berpikir kritis peserta didik. Hasil yang diperoleh dengan menggunakan uji One Way ANOVA menunjukan bahwa ada perbedaan yang signifikan dari penerapan pembelajaran E-Learning berbasis Edmodo dengan pendekatan CTL terhadap kemampuan berpikir kritis peserta didik yaitu $(\mathrm{p}=<0,05)$. Simpulan dari penelitian ini adalah penerapan pembelajaran E-learning berbasis Edmododengan pendekatan CTL lebih baik dibandingkan dengan pembelajaran E-learning berbasis Edmodo tanpa pendekatan CTL terhadap kemampuan berpikir kritis peserta didik.
\end{abstract}

Kata Kunci: Pembelajaran E-Learning, Edmodo, Contextual Teaching and Learning, kemampuanbepikir kritis.

\begin{abstract}
Edmodo is an educational application with a facebook-like social media platform that can be used in learning. In general, teachers rarely use information-based learning, communication and technology, and only focus on learning by using Liquid Crystal Display (LCD) alone without utilizing the maximum technology applications for educational purposes. The purpose of this research is to analyze the difference of critical thinking ability between learners which applied E-Learning learning based on Edmodo without Contextual Teaching and Learning (CTL) approach with students who applied E-Learning learning based on Edmodo with Contextual Teaching and Learning approach CTL). This type of research is Quasi Experimental Design with Nonequivalent Control Group Design research conducted at SMA (SLUA) Saraswati 1 Denpasar from February to April. The sample in this
\end{abstract}


research is the students of class X MIA 5 as control class and class X MIA 1 as experiment class. Critical thinking ability is measured using essay test by using rubric of critical thinking ability of learners. The results obtained by using One Way ONOVA test show that there is a significant difference from the application of Edmodo based E-Learning learning with CTL approach to students' critical thinking ability $(p=0,05)$. The conclusion of this research is the application of Edmodo based E-learning learning with CTL approach better than Edmodo based E-learning learning without CTL approach to the critical thinking ability of learners.

Keywords: Learning E-learning, edmodo, contextual teaching and learning, skills critical thinking

\section{PENDAHULUAN}

Seiring perkembangan teknologi informasi, pemanfaatan pembelajaran dalam bentuk teknologi informasi merupakan suatu keharusan guna meningkatkan efisiensi pembelajaran.Di SMA (SLUA) Saraswati 1 Denpasar memperlihatkan kondisi yang jauh dari harapan. Para guru tidak memanfaatkan pembelajaran berbasis informasi, komunikasi dan teknologi, para guru hanya fokus pada pembelajaran yang hanya menggunakan Liquid Crystal Display (LCD) tanpa memanfaatkan aplikasi teknologi secara maksimal untuk keperluan pendidikan.

Salah satu pembelajaran yang dapat membantu peserta didik dalam mempermudah berbagi informasi yang berkaitan dengan pelajaran adalah menerapkan pembelajaran E-Learning yang dapatmeningkatkan kemampuan berpikir kritis peserta didik. Pembelajaran ELearning adalah pembelajaran jarak jauh yang dalam pelaksanaannya didukung oleh jasa teknologi seperti telepon, audio, transmisi satelite atau komputer (Pradana, 2016).Untuk mencapai dan meningkatkan efektivitas tujuan pembelajaran, maka penerapan pembelajaran E-Learning berbasis Edmodo dapat diterapkan dengan menggunakan pendekatan Contextual Teaching and Learning(CTL) sehingga dapat membantu peserta didik untuk meningkatkan kemampuannya dalam berpikir kritis. Edmodomerupakan aplikasi edukasi dengan platformmedia sosial menyerupai facebookyang dapat digunakan dalam pembelajaran. Pendekatan CTL adalah sebuah proses pembelajaran yang bertujuan membantu peserta didik dalam menemukan makna dari materi yang sedang dipelajari dan menghubungkan materi yang diajarkan dengan konteks dalam kehidupan sehari-hari, sehingga kemampuan berpikir kritis peserta didik akan meningkat (Apriliani, 2011). Berpikir kritis adalah cara untuk memberikan penjelasan sederhana, membangun kemampuan dasar, menyimpulkan, memberikan penjelasan lanjut, serta mengatur strategi dan teknik. Beberapa penelitian sebelum yang dilaksanakan, salah satu diantaranya oleh Suryantari (2015) adalah menganalisis kemampuan berpikir kritis peserta didik yang diadaptasi dari Fisher. Dari penelitian-penelitian tersebut belum mencoba untuk meneliti yang mengacu pada kemampuan berpikir kritis yang diadaptasi dari Ennis (2000) yaitu peserta didik mampu merumuskan masalah, memberikan argumen, melakukan deduksi-induksi, melakukan evaluasi serta memutuskan dan melaksanakan.

Oleh karena itu penelitian ini menggunakan pembelajaran E-Learning 
berbasis Edmodo dengan Pendekatan CTL dengan tujuan untuk menganalisis perbedaan antara model pembelajaran konvensional dengan pembelajaran $E$ Learning berbasis Edmodo dengan pendekatan CTL terhadap kemampuan berpikir kritis peserta didik.

\section{METODE PENELITIAN}

\section{Desain Penelitian}

Penelitian ini merupakan penelitian eksperimen semu (QuasiExperimental Design) dengan rancangan penelitian yang digunakan adalah Nonequivalent Control Group Design(Sugiyono, 2015). Untuk menentukan sampel penelitian menggunakan teknik Simple RandomSampling sehingga didapat kelas $\mathrm{X}$ MIA 5 sebagai kelas kontrol dan X MIA 1 sebagai kelas eksperimen. Pada kelas eksperimen terdiri atas 19 orang laki-laki dan 25 orang perempuan, sedangkan pada kelas kontrol terdiri atas 24 orang laki-laki dan 20 orang perempuan, dengan rata-rata usia 17 tahun. Penelitian dilaksanakan di SMA (SLUA) Saraswati 1 Denpasar yang berlangsung pada bulan Februari2017 s/d April 2017.

\section{Prosedur Penelitian}

Perlakuan yang diberikan pada kelas eksperimen adalah penerapan pembelajaran E-Learning berbasis Edmodo dengan pendekatan $C T L$ sedangkan pada kelas kontrol hanya diberikan pembelajaran E-Learning berbasis Edmodo tanpa pendekatan CTL. Proses pembelajaran dilaksanakan di dalam kelas maupun di luar kelas dengan pembelajaran E-Learning berbasis Edmodo mengenai materi Perubahan Lingkungan yang berhubungan langsung dengan kehidupan nyata peserta didik sebanyak 3 kali pertemuan. Pembelajaran didalam kelas pada
Pertemuan pertama, adalah perkenalan dan penjelasan mengenai model dan media pembelajaran yang akan diterapkan didalam kelas kemudian dilanjutkan dengan pelaksanaan tes awal (pretest) baik pada kelas kontrol maupun kelas eksperimen. Pertemuan kedua, adalah menerapkan tahap-tahap atau sintak dari model pembelajaran yang digunakan yaitupembelejaran dengan pendekatan $C T L$ pada kelas eksperimen, dimulai dari tahap Modelling, tahap Questioning, tahap Learning Community, tahap Inquiry, tahap Contructivism. Pembelajaran diluar kelas adalah pembelajaran E-learning berbasis Edmodoyaitu berdiskusi dan mengirim file dan tugas melalui media Edmodo dengan memanfaatkan fitur-fitur Edmodo yang ada, seperti misalnya fitur Assigment yang dapat membantu dalam memberikan tugas kepada peserta didik diluar jam pelajaran dalam jangka waktu tertentu. Dan pada pertemuan ketiga, adalah pada tahap Reflection dan Authentic Assessment yaitu mengevaluasi pembelajaran yang telah dilaksanakan dan pemberian penghargaan (Reward) bagi setiap kelompok yang memiliki kinerja terbaik. Kemudian dilanjutkan dengan pemberian tes akhir (posttest). Data dikumpulkan dengan menggunakan rubrik kemampuan berpikir kritisyang sebelumnya sudah diuji validitasdan reliabilitas dengan menggunakan uji Alpha Cronbach, sehingga dapat digunakan dalam penelitian.Berdasarkan hasil perhitungan tingkat kesukaran soal dan daya pembeda soal dapat disimpulkan bahwa 15 item soal uraian diterima (valid) dan 5 item soal direvisi. Sedangkan hasil uji Alpha Cronbach dapat disimpulkan intrumen berpikir kritis peserta didik reliabel karena memiliki nilai alpha yang lebih besar dari 0,60 . 
Tes berpikir kritis diberikan dalam bentuk tes essay yang terdiri dari 5 indikator.Adapun 5 indikator kemampuan berpikir kritis yang dinilai yaitu merumuskan masalah (MM), memberikan argumen (MA), melakukan deduksi (MD), melakukan induksi (MI), melakukan evaluasi (ME) serta memutuskan dan melaksanakan (ML) diadaptasi dari (Ennis, 2000). Data dianalisis secara deskriptif dan inferensial dengan taraf signifikansi $\mathrm{p}=0,05$. Analisis deskriptif melalui penyajian tabel dan histogram, sedangkan analisis inferensial dengan menggunakan uji One Way ANOVA(Sugiyono, 2015). Analisis ini dilakukan untuk mengetahui peningkatan kemampuan berpikir kritis peserta didik antara kelas kontrol dan kelas eksperimen.

\section{HASIL DAN PEMBAHASAN Hasil}

Pemaparan hasil penelitian meliputi hasil analisis kemampuan berpikir kritis peserta didik baik secara deskriptif maupun hasil analisis secara inferensial dengan menggunakan uji One Way ANOVA untuk jumlah keseluruhan komponen kemampuan berpikir kritis.

\section{1) Hasil Analisis Deskriptif Kemampuan Berpikir Kritis Peserta didik}

Hasil perbandingan rata-rata jumlah skor kemampuan berpikir kritis peserta didik pada kelas kontrol dan kelas eksperimen terdapat pada Tabel 1 sebagai berikut:

Tabel 1 Perbandingan Rata-rata Jumlah Skor Kemampuan Berpikir Kritis Peserta Didik pada Kelas Kontrol dan Kelas Eksperimen

\begin{tabular}{|c|c|c|c|c|}
\hline \multirow{3}{*}{ Variabel } & \multicolumn{4}{|c|}{ Kemampuan Berpikir Kritis } \\
\hline & \multicolumn{2}{|c|}{$\begin{array}{c}\text { Kelas Kontrol } \\
\mathrm{N}=44\end{array}$} & \multicolumn{2}{|c|}{$\begin{array}{l}\text { Kelas Eksperimen } \\
\qquad \mathrm{N}=44\end{array}$} \\
\hline & Pretest & Posttest & Pretest & Posttest \\
\hline Jumlah skor & 1660 & 2224 & 1871 & 2891 \\
\hline Rata-rata & 37,72 & 50,54 & 42,52 & 65,70 \\
\hline Standar Deviasi & 2,97 & 5,60 & 5,64 & 5,68 \\
\hline$>\bar{X}$ & 0 & 22 & 9 & 44 \\
\hline$<\bar{X}$ & 44 & 22 & 35 & 0 \\
\hline
\end{tabular}

Berdasarkan Tabel 1 menunjukkan bahwa peserta didik kelas eksperimen memperoleh nilai rata-rata dan standar deviasi pretest $(42,52 \pm 5,64)$ dan posttest $(65,70 \pm 5,68)$ lebih tinggi dibandingkan kelas kontrol dengan rata-rata dan standar deviasi pretest $(37,72 \pm 2,97)$ dan posttest $(50,54 \pm 5,60)$. Hasil tersebut juga menunjukkan bahwa terdapat perbedaan jumlah peserta didik yang memperoleh nilai diatas rata-rata $(\geq \bar{X})$ dan dibawah rata-rata $(<\bar{X})$. Pada kelas eksperimen yang mendapatkan nilai diatas rata-rata saat pretest adalah sebanyak 9 peserta didik dan meningkat pada saat posttest sebanyak 44 peserta didik, sedangkan yang mendapatkan nilai dibawah rata-rata saat pretest adalah sebanyak 35 peserta didik dan pada saat posttest tidak ada peserta didik yang mendapat nilai dibawah ratarata. Jika ditinjau berdasarkan komponen kemampuan berpikir kritis yang diukur kelas eksperimen dengan pembelajaran $E$ - 
Learning berbasis Edmodo dengan pendekatan CTL memperoleh skor nilai diatas rata-rata $(\geq \bar{X})$ lebih banyak dibandingkan pada kelas kontrol. Pada kelas kontrol saat pretest tidak ada peserta didik yang mendapatkan nilai diatas ratarata dan pada saat posttest meningkat sebanyak 22 peserta didik, sedangkan yang mendapatkan nilai dibawah rata-rata saat pretest adalah sebanyak 44 peserta didik dan pada saat posttest sebanyak 22 peserta didik yang mendapat nilai dibawah rata-

2) Hasil Analisis Deskriptif Kemampuan Berpikir Kritis Peserta didik Per Komponen

Ditinjau dari nilai rata-rata per komponen berpikir kritis peserta didik yang telah diamati, terdapat perbedaan antara kelas ekperimen dan kelas kontrol. Perbandingan nilai rata-rata per komponen berpikir kritis peserta didik kelas eksperimen dan kelas kontrol disajikan dalam histogram pada Gambar 1. rata.

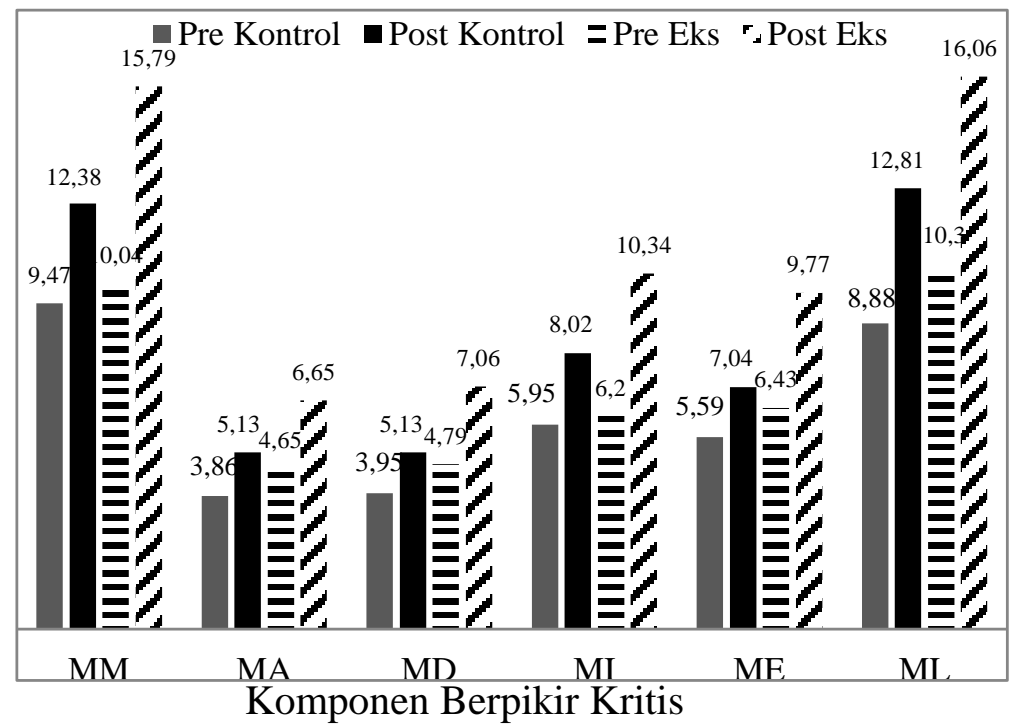

Gambar 1 Perbandingan nilai rata-rata kemampuan berpikir kritis per komponen yang diukur. MM (Merumuskan Masalah), MA (Memberikan Argumen), MD (Melakukan Deduksi), MI (Melakukan Induksi), ME (Melakukan Evaluasi), dan ML (Memutuskan dan Melaksanakan)

Berdasarkan Gambar 1 terlihat bahwa nilai rata-rata kemampuan berpikir kritis per komponen yang memperoleh skor tertinggi pada kelas eksperimen yaitu komponen ML saat pretest $(10,38)$ dan posttest (16,06), sedangkan komponen yang memperoleh skor terendah pada kelas eksperimen yaitu komponen MA saat pretest $(4,65)$ dan posttest $(6,65)$. Sama halnya pada kelas kontrol yang memperoleh skor tertinggi yaitu komponen
ML saat pretest $(12,81)$ dan posttest $(8,88)$, sedangkan komponen yang memperoleh skor terendah pada kelas kontrol yaitu komponen MA saat pretest $(3,86)$ dan posttest $(5,13)$.

Beberapa fitur-fitur Edmodo yang ada, seperti misalnya, fitur file and link, fitur Assignment dan fitur Quis juga sangat membantu dalam mendukung kemampuan berpikir kritis peserta didik 
3) Hasil Analisis Inferensial Kemampuan Berpikir Kritis Peserta didik dengan Uji One Way ANOVA

Berdasarkan hasil uji One Way ANOVA terhadap kemampuan berpikir kritis peserta didik menunjukkan perbedaan nyata antara kelas kontrol dengan kelas eksperimen, hasil selengkapnya terdapat pada Tabel 2 sebagai beriku.

Tabel 2 Hasil Uji One Way ANOVA Kemampuan Berpikir Kritis Peserta didik

\begin{tabular}{cc}
\hline Uji One Way ANOVA & Kemampuan Berpikir Kritis Peserta didik \\
\hline F & 158,674 \\
Sig. & 0,000 \\
\hline
\end{tabular}

Ditinjau dari hasil analisis uji One Way ANOVA yang telah dilakukan terhadap jumlah keseluruhan dari kelima komponen kemampuan berpikir kritis peserta didik menunjukkan perbedaan yang nyata pada jumlah keseluruhan masing-masing komponen berpikir kritis peserta didik dengan taraf signifikansi $(\mathrm{p}=0,000<0,05)$. Dari hasil uji One Way ANOVA tersebut menunjukkan bahwa hipotesis alternatif diterima yaitu terdapat perbedaan kemampuan berpikir kritis antara peserta didik yang diterapkan pembelajaran $E$ Learning berbasis Edmodo tanpa pendekatan $C T L$ dengan peserta didik yang diterapkan pembelajaran E-Learning berbasis Edmodo dengan pendekatan $C T L$.

\section{PEMBAHASAN}

1) Pembahasan Hasil Analisis Kemampuan Berpikir Kritis Peserta didik

Kemampuan berpikir kritis peserta didik pada kelas eksperimen memperoleh rata-rata skor lebih tinggi dibandingkan kelas kontrol.Hasil tersebut juga menunjukkan bahwa terdapat perbedaan jumlah peserta didik yang memperoleh nilai diatas rata-rata pada kelas eksperimen lebih banyak dibandingkan kelas kontrol.Pada kelas eksperimen sebelum diterapkan pembelajaran E-Learning berbasis Edmodo dengan pendekatan $C T L$, jumlah peserta didik yang memperoleh nilai dibawah ratarata lebih banyak dibandingkan peserta didik yang memperoleh nilai diatas ratarata.Setelah diterapkannya pembelajaran $E$ Learning berbasis Edmodo dengan pendekatan $C T L$ jumlah peserta didik yang memperoleh nilai diatas rata-rata pada kelas eksperimen adalah seluruh peserta didik kelas eksperimen. Pada kelas kontrol pembelajaran yang digunakan adalah pembelajaran E-Learning berbasis Edmodo tanpa pendekatan CTL, sehingga proses pembelajaran pada kelas kontrol lebih menekankan pada penyelesaian materi atau tugas yang diberikan oleh guru dan peserta didik kurang termotivasi dalam mendorong diri mereka sendiri untuk meningkatkan kemampuannya dalam berpikir kritis.

Proses pembelajaran tersebut melibatkan ingatan memori jangka pendek (recall short term memory) peserta didik dalam kegiatan bermakna yang akan disimpan dalam bentuk ingatan memori jangka panjang (long term memory). Pembelajaran dengan pendekatan CTL berakar dari pendekatan konstruktivistik bahwa seseorang atau peserta didik melakukan kegiatan belajar dengan membangun pengetahuan melalui interaksi dan interpretasi di lingkungannya.Sehingga seorang yang kritis memiliki kemampuan untuk terusmenerus memperlakukan dunia sekitarnya 
dengan mencari dan menerima informasi dengan membandingkan dan menganalisis setiap informasi yang diterima dengan pemikiran yang efektif yang menunjukkan kemampuan untuk berpikir logis dan konsisten dengan kemampuan untuk memecahkan masalah secara cepat dan logis (Kopzhassarova, $d k k$. 2016).Hal tersebut sejalan dengan pendapat Duron, $d k k$.(2006) yang menyatakan bahwa berpikir kritis adalah berlatih atau memasukkan penilaian atau evaluasi yang cermat, seperti menilai kelayakan suatu gagasan atau produk.

\section{2) Pembahasan Hasil Analisis Kemampuan Berpikir Kritis Peserta Didik Per Komponen}

Berdasarkan hasil kemampuan berpikir kritis peserta didik menunjukkan bahwa terdapat perbedaan rata-rata yang dihitung per komponen pada kelas eksperimen dan kelas kontrol.Masing-masing komponen pada kelas eksperimen memperoleh skor lebih tinggi dari kelas kontrol. Pada kelas eksperimen dan kelas kontrol, komponen kemampuan berpikir kritis dengan skor tertinggi yaitu pada komponen Memutuskan dan Melaksanakan (ML), hal ini disebabkan karena Memutuskan dan Melaksanakan (ML) pada komponen kemampuan berpikir kritis merupakan komponen yang lebih banyak di bahas dalam soal essay yang diberikan dibandingkan dengan komponen yang lainnya, sehingga komponen ML tersebut memperoleh skor tertinggi pada peserta didik kelas eksperimen maupun kelas kontrol. Tetapi nilai rata-rata ML pada kelas eksperimen mendapatkan nilai yang lebih tinggi bila dibandingkan dengan nilai MA pada kelas kontrol.

Faktor lain yang mempengaruhi hal tersebut adalah karena penerapan pembelajaran E-Learning berbasis Edmodo. Dengan adanya penerapan pembelajaran $E$ Learning berbasis Edmodo, diluar kelas peserta didik dapat berkomunikasi dengan guru dan sesama peserta didik terhadap halhal yang belum dipahami saat pembelajaran didalam kelas yang mendukung kemampuan berpikir kritis peserta didik.Dalam hal ini bahwa fitur-fitur Edmodo yang ada, seperti misalnya, fitur file and link, fitur Assignment dan fitur Quis juga sangat membantu dalam mendukung kemampuan berpikir kritis peserta didik. Seperti fitur File and link digunakan oleh guru dan peserta didik untuk mengirimkan pesan dengan melampirkan file and link pada grup kelas. Pada fitur ini juga, peserta didik bisa dengan leluasa dalam berkomunikasi dengan guru dan sesama peserta didik dan bertanya mengenai hal-hal berkaitan dengan pembelajaran dikelas yang belum dimengerti. Fitur lain dalam Edmodo yang membantu kemampuan berpikir kritis peserta didik adalah Assignment. Fitur ini digunakan oleh guru untuk memberikan penugasan kepada peserta didik secara online.Fitur ini dilengkapi dengan waktu deadline sehingga peserta didik dapat mengirim tugas yang diberikan secara langsung kepada guru tanpa melewati jangka waktu yang telah ditentukan.Selain daripada fitur-fitur Edmodo diatas, juga terdapat fitur yang sangat membantu dalam kemampuan berpikir kritis peserta didik yaitu fitur Quis.Fitur ini digunakan oleh guru untuk membarikan evaluasi secara online baik berupa soal uraian, pilihan ganda ataupun isian singkat. Sehingga dengan adanya beberapa fitur Edmodo tersebut sangat mendukung proses pembelajaran diluar kelas.

Hal ini sejalan dengan penelitian Rahmaningrum (2016) yang menemukan 
bahwa dengan menerapkan pembelajaran E-Learning berbasis Edmodo berpengaruh terhadap hasil belajar peserta didik.Sedangkan komponen kemampuan berpikir kritis dengan skor terendah baik pada kelas eksperimen dan kelas kontrol yaitu pada komponen Melakukan Argumen (MA).Hal ini disebabkan karena komponen Melakukan Argumen (MA) merupakan komponen yang lebih sedikit di bahas dalam soal essay yang diberikan dibandingkan dengan komponen yang lainnya, disamping itu peserta didik pada kelas eksperimen maupun kelas kontrol belum mampu membangun kemampuan dasar yang terdiri atas mempertimbangkan apakah sumber dapat dipercaya atau tidak.Tetapi nilai rata-rata MA pada kelas eksperimen mendapatkan nilai yang lebih tinggi bila dibandingkan dengan nilai MA pada kelas kontrol. Hal ini dikarenakan pada kelas eksperimen menerapkan pembelajaran E-Learning berbasis Edmodo dengan pendekatan CTL dimana pada tahapan Inquiry dan Constructivism melatih peserta didik untuk mampu melakukan indentifikasi, investigasi dan membangun pemahaman sendiri. Sedangkan pada kelas kontrol pembelajaran yang dilakukan adalah dengan pembelajaran E-Learning berbasis Edmodo tanpa pendekatan CTL, sehingga pembelajaran dikelas kontrol lebih menekankan pada ketuntasan materi atau tugas yang diberikan oleh guru sehingga peran peserta didik lebih terbatas dan hanya menunggu instruksi dari guru, dengan demikian kegiatan pembelajaran menjadi kurang bergairah dan tidak ada pengaruh terhadap kemampuan berpikir kritis peserta didik.

Berdasarkan hasil analisis data dengan uji One Way ANOVA terhadap kemampuan berpikir kritis peserta didik menunjukkan bahwa terdapat perbedaan kemampuan berpikir kritis peserta didik antara kelas eksperimen dan kelas kontrol. Sehingga dapat disimpulkan bahwa yang diterapkan pembelajaran E-Learning berbasis Edmodo dengan pendekatan CTL berpengaruh terhadap kemampuan berpikir kritis peserta didik dibandingkan dengan peserta didik yang diterapkan pembelajaran E-Learning berbasis Edmodo tanpa pendekatan CTL.

\section{PENUTUP}

\section{Simpulan}

Penerapan pembelajaran E-learning berbasis Edmodo dengan pendekatan Contextual Teaching and Learning (CTL) berpengaruh nyata $\quad(\mathrm{p}=0,000<0,05)$ terhadap kemampuan berpikir kritis peserta didik SMA (SLUA) Saraswati 1 Denpasar.

Kemampuan berpikir kritis peserta didik yang diterapkan pembelajaran $E$ learning berbasis Edmodo dengan pendekatan $C T L$ meningkat dan lebih baik dibandingkan dengan peserta didik yang diterapkan pembelajaran E-learning berbasis Edmodo tanpa pendekatan $C T L$.

Keterbatasan dalam penelitian yang berjudul penerapan pembelajaran $E$ learning berbasis Edmodo dengan pendekatan CTL terhadap kemampuan berpikir kritis peserta didik adalah kurang menekankan pada pelaksanaan dalam menggunakan berbagai fitur-fitur yang ada dalam halaman Edmodo dan masih kurangnya variabel-variabel lain yang terkait seperti berpikir kreatif dan self confident peserta didik dan lain-lain.

\section{UCAPAN TERIMA KASIH}

Ucapan terima kasih penulis sampaikan kepada Ir.I Made Budiadnyana selaku kepala sekolah yang telah memberikan ijin penelitian, Ibu Dra. Putu 
Lilik Lelyani, M.Pd dan Ibu Ir. I Ketut Damayanti selaku guru biologi yang telah membantu selama penelitian dan peserta didik SMA (SLUA) Saraswati 1 Denpasar yang telah bersedia menjadi subjek penelitian.

\section{DAFTAR PUSTAKA}

Apriliani, D. (2011). Pengaruh penggunaan metode E-Learning berbasis Moodle dengan pendekatan CTL (contextual teaching and learning) terhadap hasil belajar kimia materi pokok larutan elektrolit dan konsep redoks siswa sma kelas $x$. Skripsi. [PDF document]. Diunduh pada tanggal 25 September 2016 dari http://lib.unnes.ac.id/7180/

Duron, R., Limbach, B., \& Wough,W. (2006). Critical Thinking Framework for Any Dicipline.International Journal of Teaching and Learning in Higher Education. Vol. 2, No 2, Tahun 2006

Ennis, R.H. (2000). Critical thinking.United States Of America : Pretice Hell. Inc. Journal Vol 18, No 2, Tahun 2001.Diunduh pada tanggal 11 Januari 2017 darihttp://137.207.184.83/ojs/leddy/ind ex.php/informal_logic/article/view/238

Kopzhassarova, U., Akbayeva, G., Eskazinova, Z., Belgibayeva. G.,\& Tazhikeyeva. A. (2016).Enhancement of Students' Independent Learning Through Their Critical Thinking Skills Development. International Journal of Environmental \& Science Education, Vol.11, No.18, Tahun 2016. Diunduh pada tanggal 5 Mei 2017 dari http://www.ijese.net/makale/1619

Pradana, M., \& Naris, W.A. (2016). Measuring e-learning effectiveness at indonesian private university. International Journal Of Environmental
\& Science Education, Vol.11, No.18, Tahun 2016. Diunduh pada tanggal 5 Mei 2017 dari http://www.ijese.net/makale/1613

Rahmaningrum, V. N. (2016). Pengaruh media pembelajaran E-learning berbasis Edmodo pada mata pelajaran penerapan rangkaian elektronika untuk meningkatkan hasil belajar siswa kelas XI Teknik Audio Video Di SMK Negeri 3 Surabaya.Jurnal Pendidikan Teknik Elektronik, Vol. 5, No. 3 Tahun 2016. [PDF document].Diunduh pada tanggal 20 Maret 2017 dari http://jurnalmahasiswa.unesa.ac.id/ind ex.php/jurnal-pendidikan-teknikelektro/article/view/15970.

Sugiyono. (2015). Metode penelitian pendidikan pendekatan kuantitatif, kualitatif dan $R \quad \& \quad D$. Bandung: Alfabeta.

Suryantari, N.W.H. (2015). Implementasi model pembelajaran project based learning $(P j B L)$ dengan media mind mapping 3 dimensi terhadap kreativitas dan kemampuan berpikir kritis siswa SMA Negeri 7 denpasar. Skripsi. Pendidikan Biologi, Universitas Mahasaraswati. 